Szomju László ${ }^{1}-$ Habók Anita ${ }^{2}$

Bálint Márton Általános Iskola és Középiskola, Törökbálint*

Szegedi Tudományegyetem, Neveléstudományi Intézet**

\title{
Matematikai szöveges feladatok és tanulási szokások kapcsolatának vizsgálata
}

Kutatások igazolták (Csapó, 2002, Csíkos, 2012), hogy a matematika nem tartozik a legkedveltebb tantárgyak közé. A tantárgyon belül az egyik legösszetettebb anyagrész pedig a szöveges feladatoké.

A mindennapi életben legtöbbször szöveges kontextusból kell kiválasztani a releváns adatokat, melyhez szükség van például a szöveg megértésére és értelmezésére (Józsa, 2006), a probléma megértésére (Dobi, 2002), valamint a számolási készségre (Nagy, 2007). A tanulmány a matematikai szöveges feladatok megoldását állitja a középpontba mindennapi élethez kötôdó szituációkon keresztül. Ezen túl a tanulás nem kognitiv összetevóinek vizsgálatára is sor kerül a tanulási szokásokon keresztül. A tanulmány továbbá

választ ad arra, hogy a matematika teszt eredményei mely változókkal állnak kapcsolatban a tanulási szokások kérdóivból.

A Nemzeti Alaptanterv (2012) a matematikai kompetencia kialakulásának elengedhetetlen feltételeként szabja meg azoknak a készségeknek a kialakítását, amelyekre támaszkodva a mindennapi problémák megoldása során a matematikai ismereteket alkalmazzuk. Alapvető fontosságú, hogy a tanulók ki tudják választani és képesek legyenek alkalmazni a természeti és társadalmi jelenségekhez illeszkedő modelleket és gondolkodásmódokat. Az alaptanterv szerint a diákoknak meg kell tudniuk ítélni egy feladat kapcsán azt, hogy az tartalmaz-e felesleges vagy ellentmondó adatot, illetve van-e elegendő információ a szövegben a kérdés megválaszolásához. A tanulóknak össze kell tudni vetni a kapott eredményt a feltételekkel és a valósággal, valamint számba kell tudni venni az összes adódó lehetőséget a megoldáshoz. A matematikaoktatás szempontjából ez arra hívja fel a figyelmet, hogy a kizárólag szimbólumokat használó, algoritmikus, képetekbe behelyettesítő mechanikus eljárások helyett elötérbe kerülnek a valós környezetbe ágyazott problémák, melyekkel a tanulók a mindennapi életben is találkozhatnak.

Az utóbbi évtizedek pedagógiai kutatásai egyértelműen kimutatták, hogy a tanulók teljesítményei csak részben magyarázhatók kizárólag a tudás kognitív összetevőivel, a tanulás egyéb, nem kognitív tényezőinek szerepe is lényeges az eredményes tanulás szempontjából. Vizsgálatok középpontjában állt például a tanulók tanulási stratégiáinak, motivációjának, meggyőződéseiknek vizsgálata (B. Németh és Habók, 2006; Csíkos, Kelemen és Verschaffel, 2011; Habók, 2013; Józsa, 2007). Összességében a tanulásról alkotott komplex képet a kognitív, affektív és metakognitív dimenziói adják (Hoskins és Fredriksson, 2008). 
A következőkben a mindennapi élethelyzetekhez kötődő matematikai szöveges feladatok és a tanulási szokások elméletének bemutatására kerül sor. Ezután egy kérdőíves vizsgálat eredményeinek ismertetése történik, mely egyrészt iskolai környezetben szokásos feladatokra, másrészt a tanítás során ritkán előforduló, de a fejlesztési célok szempontjából lényeges matematikai problémákra épült. Végül a kérdöív és a tanulási szokások közötti kapcsolatok ismertetése történik.

\section{Elméleti háttér}

\section{Matematikai szöveges feladatok}

Alsó tagozaton matematikát tanító pedagógusok gyakran említik a szöveges feladatokat, mint a legproblémásabb anyagrészt munkájuk során. A Vanderbilt Egyetem középiskolai tanulók számára fejlesztett kísérlete során a kutatásba bevont gyakorlott középiskolai tanárok szintén a szöveges feladatokat emelték ki a legintenzívebben fejlesztendő területek közül (Józsa és Székely, 2004). Ez azonban nem is meglepö, hiszen nagyon összetett a szöveges feladatok megoldása, a szövegmegértésnek, értelmezésnek, a gondolkodási müveletek használatának és a problémamegoldásnak is szerep jut.

Általános értelemben akkor beszélünk problémáról, amikor egy adott szituációból akarunk eljutni egy adott célállapotba, de nem tudjuk az odavezető utat. Egy probléma leírásában három elem szerepel: (1) kiindulási állapot, (2) célállapot és (3) megengedett operációk. A problémamegoldás, azaz a problémaalapú gondolkodás, olyan kognitív folyamat, amely lehetővé teszi, hogy megtaláljuk a megoldáshoz vezető utat. Matematikai problémáról beszélünk, ha a megoldás során matematikai eljárásokat (aritmetikai, algebrai stb.) kell alkalmazni. A matematikai problémák közül megkülönböztethetjük a rutinszerü és a nem rutinszerü problémákat. Rutinszerü problémáról akkor beszélünk, ha a megoldó azonnal tudja, hogyan hajtsa végre a megoldási eljárást. Szigorú értelemben véve ezek nem is problémák, gyakran matematikai feladatként említjük őket. A megoldó szemszögéből kell nézni, az ő szempontjából egy szöveges feladat lehet rutinszerü, míg egy másik pedig nem az, nincs éles határvonal a két típus között (Mayer és Hegarty, 1998, idézi Sternberg és Ben-Zeev, 1998). Molnár (2001) nyomán megállapíthatjuk, hogy a problémamegoldás komplex folyamat, melynek során nemcsak jól, de rosszul definiált problémákkal is találkozunk, talán ezekkel gyakrabban is a mindennapi életben. Ebben az esetben nekünk kell megoldani a problémát a célok meghatározásán, a megoldási módszerek megkeresésén keresztül, és nekünk kell értelmezni a végeredményt. Meghatározó az is, hogy az iskolai feladatok gyakran egy-egy tudományterülethez, tantárgyhoz, témakörhöz kötődnek, és a tanulóktól nem várják el, hogy ismereteiket transzferálják. A gyakorlati életben előforduló problémák azonban több ismeretet igényelnek. Hátráltathatja az is a tanulókat a problémamegoldás során, hogy olyan feladatokat kapnak az iskolában, melyekben minden adatot fel kell használni, és általában annyi információt kapnak, mint amennyi szükséges a megoldáshoz. Egy gyakorlati probléma szituációban azonban előfordulhat, hogy jóval több információra van szükség, mint ami rendelkezésre áll, így nincs is megoldása, vagy a sok rendelkezésre álló információ közül kell kiválasztani, ami szükséges a megoldáshoz. Molnár (2001) hangsúlyozza azt is, hogy az iskolák fóként a transzparens problémákat használják, míg a tanulók nagyobb valószínüséggel találkoznak olyan problémával a gyakorlati éltben, melyet elöször tisztázni, értelmezni kell, mielőtt elkezdik megoldani.

A matematikai szöveges feladatok értelmezése széles körü. Tágabb értelemben matematikai szöveges feladatnak tekinthetünk minden olyan szövegesen megfogalmazott problémát, amelynek megoldása során a matematika valamely területének használata 
szükséges. Ilyen módon beszélhetünk például geometriai, kombinatorikai, valószínűség-számítási feladatokról, attól függően, hogy a probléma „mélystruktúrája” milyen matematikai területet érint. A vizsgálatban kizárólag egyszerü aritmetikai müveletekkel megoldható szöveges példák szerepelnek, amelyeket számtani szöveges feladatoknak is nevezhetünk.

Csíkos 2003-as tanulmányában a matematikai szöveges feladatok kutatásával kapcsolatban három mérföldkövet azonosít: (1) Az egyszerü, szekvenciális modell esetében egyszerü, egy müvelettel megoldható számtani szöveges feladatok megoldása áll a középpontban (W. Kintsch és J. G. Greeno, 1985, idézi Csíkos, 2003). Attól függően különböztetik meg a szöveges problémák típusait, hogy melyik adatra és milyen formában kérdezünk rá. A feladatmegoldás egymás utáni lépések sorozatából áll. A lépések számát nagymértékben az határozza meg, hogy hányszor kell a munkamemóriában új egységet szerepeltetni. A modell hátránya tartalomfüggetlensége, tehát nem tudja kezelni azt a tényt, hogy nem mindegy, milyen objektumok szerepelnek a szövegben. (2) A reprezentáció szerepét hangsúlyozó modell (Mayer és M. Hegarty, 1998, idézi Sterberg és Ben-Zeev) szintén az egyetlen alapmüvelettel megoldható feladatokkal foglalkozik, de túllép a szekvenciális modellen, és számításba veszi a tartalom szerepét, azaz a probléma megfelelö reprezentációját. A problémamegoldásnak négy szakaszát különböztetik meg, a transzlációt, az integrálást, a tervezést és a végrehajtást. (3) A realisztikus feladatok meghatározása Csíkos és Kelemen (2009) szerint négyféle megközelítésből történhet. (a) A legkevésbé szigorú meghatározás szerint a realisztikus feladatokban a hétköznapi élet objektumai és ezek viszonyai fordulnak elő. (b) A második típusba azokat a feladatokat sorolhatjuk, amelyek esetén követelmény a relevancia és a közvetlen tapasztalat. (c) A harmadik értelmezés szerint a realisztikus feladatokban a megoldási menet során legalább egyszer szerephez jutnak a hétköznapi ismeretek. Gyakran a végeredmény realitásának megállapításánál, a hiányzó adatok pótlásánál, illetve a fölösleges adatok kiszürésénél kapnak szerepet a mindennapi élet során szerzett tapasztalatok. A bemutatott vizsgálatban ez a típus fordul elö. (d) A negyedik típusba azok a szöveges feladatok tartoznak, ahol az azonnali megoldás útjának hiánya jellemző.

Csíkos Csaba (2007) Metakogníció címü kötetében jellemzi azt az öt tudáskategóriát, amelyet Eric de Corte a problémamegoldó gondolkodásban való jártasság szempontjából a leglényegesebbnek tart. Az öt kategória a következő: (1) tartalomspecifikus alaptudás, a (2) heurisztikus problémamegoldó stratégiák, a (3) metatudás, az (4) önszabályozás és a (5) meggyőződések.

(1) A tartalom specifikus alaptudás jelenti például a matematikai számolási algoritmusokat, a kutatási eredmények szerint ezzel a tudáskategóriával van a legkevesebb gondja a tanulóknak, ezeket gyakorolják órán a legtöbbet drillszerüen. Ehhez a kategóriához értelmezésre nincs is feltétlenül szüksége a tanulóknak. (2) A heurisztikus problémamegoldó stratégiák teszik például lehetővé az adatok szisztematikus kigyüjtését, a probléma szempontjából releváns információk azonosítását, a szükséges matematikai műveletek meghatározását. (3) A metatudás és az (4) önszabályozó folyamatok egymással összefüggenek. A metatudás elsősorban a saját tudásunkról való tudást jelenti, melyben nagy szerep jut az önszabályozó folyamatoknak, a gondolkodással és az akarattal kapcsolatos faktoroknak (Csikos, 2007).

Az utóbbi két évtizedben nagy figyelem fordult a tanulói (5) meggyőződések vizsgálata felé a matematikai tudáshoz kapcsolódóan ('mathematical beliefs'). Az angol 'belief' kifejezés a szakirodalomban olyan tudáselemekre vonatkozik, amelyek összeköttetést jelentenek az affektív és a kognitív szféra között. A meggyőződéseket érdemes szubjektív, tapasztalaton alapuló implicit ismeretekként kezelni. A szubjektív jelző az affektív tulajdonságokra utal, az implicit kifejezés pedig azt jelenti, hogy az egyén gyakran nehezen vagy egyáltalán nem képes megfogalmazni meggyőződéseit (Csikos és Kelemen, 
2009), éppen ezért a kutatásához a kvalitatív módszerek mellett kvantitatív forma részletesebb információval szolgálhat. A tanulói meggyőződések direkt módon történő vizsgálatára az interjúmódszer jó lehetőséget ad (Csikos, 2007).

Meg kell említeni azokat az iskolára jellemző kommunikációs mintákat és társadalmi kölcsönhatásokat, melyeket a szakirodalomban „didaktikai egyezményként” neveznek meg. Ha a tanítási órákon a feladatmegoldást olyan formában szervezik meg, hogy a tanár először bemutatja a feladatot, majd a diákok ezt begyakorolják, azaz a szöveges feladatokat csak a számolások gyakoroltatására használják, akkor logikusnak tünhet, hogy a tanulók begyakorolják a sztereotip megoldási megközelítéseket. A rutinná váló, mechanikus, drillezésen alapuló feladatmegoldás, valamint a szöveg jelentésének figyelmen kívül hagyása gyakran abban jelenik meg, hogy a diákok hajlandók elfogadni ésszerütlen válaszokat, melyek a gyakorlati életben nem fordulhatnak elö, és nem életszerúek (Wyndhamn és Säljö, 1997).

A begyakorolt feladatmegoldási sémák után kérdés az, hogy a téves tanulói meggyőződéseket milyen módon lehet megváltoztatni. Kutatások igazolták, ha a tanulók figyelmét felhívták arra, hogy nem feltétlenül van minden feladatnak megoldása, és ügyeljenek a végeredmény valósággal való összehasonlítására, akkor sem volt szignifikáns változás az eredményességben (Csíkos, 2007). Ez is azt erősíti meg, hogy a tanítási-tanulási folyamat során kialakult „didaktikai egyezmények” erősen jelen vannak a tanulók gondolkodásában, és minimális beavatkozással nem változtathatók meg. Megváltoztatásukra ad lehetőséget például a reflektív tanítási-tanulási módszer használata (Szendrei, 2005), a metakognitív tanulási stratégiák fejlesztéséhez kapcsolódó programok (Csíkos, 2007) és a meggyőződések vizsgálatához kapcsolódó programok (Mason és Scrivani, 2004). Mason és Scrivani (2004) utalt arra, hogy azok a tanulók, akik innovatív tanulási környezetbe kerültek, más típusú meggyőződésekkel rendelkeztek a fejlesztő programjuk végére, mint azok, akiket hagyományos módon tanítottak. A feladatról, a problémamegoldásról való tapasztalatcsere, reflektálás pozitív hatással volt a meggyőződések alakulására és a problémamegoldó képességek fejlődésére. A tanulók a realisztikus problémákat is pontosabban oldották meg, és azokat is pontosabban azonosították, melyeknek nem volt megoldása. A realisztikus feladatok megoldásának sikeréhez nagymértékben hozzájárul az, ha a tanulók találkoztak már iskolai környezetben realisztikus meggondolást igénylö feladattal, adathiányos vagy megoldhatatlan problémával. A belső, hozott tapasztalatok és elöismeretek eredményezik a realisztikus reakciók növekedését (Kelemen, 2004).

\section{Tanulási szokások, a tanulók viszonya a tanuláshoz}

A tudásalapú társadalom fontos alapeleme, hogy olyan tagjai legyenek, akik képesek az élethosszig tartó tanulásra. A PISA 2000 vizsgálatban jelent meg először a tanulási szokások vizsgálata, mely a kognitív területeken túl a tanulási jellemzők meghatározásával is foglalkozott (Artelt, Baumert, Julius-McElvany és Peschar, 2003). A kérdőív elméleti alapját az önszabályozó tanulás adta. A téma hazai kutatásában kiemelkednek D. Molnár Éva publikációi. Az utóbbi évtizedekben a tanulást úgy értelmezik, mint a tanuló által kontrollált, vezérelt, megerősített és figyelemmel kísért folyamatot. Ezek a megfogalmazások vezettek el az önszabályozó, vagy az újabb fordítás alapján az önszabályozott tanulás fogalmához (Molnár, 2013). Az elméleti megközelítések metakognitív, motivációs és a viselkedési folyamatok szempontjából jellemzik a fogalmat. Lásd például Dignath, Buettner és Langfeldt (2008) metaanalízisét az önszabályozó tanulás elméletéről és hozzá kapcsolódó fejlesztő programokról. Metakognitív szempontból az önszabályozó tanuló tervez, szervez, cselekszik és visszacsatolást végez. A motivációt hangsúlyozó elméletek az önhatékonyságban való hit és a belső motiváció fontosságát emelik ki. Az 
önszabályozó tanuló szelektál, strukturál, és úgy alakítja környezetét, hogy az leginkább segítse tanulási folyamatát. Az önszabályozó tanulás legfontosabb hozadékának azt tekinthetjük, hogy a tanulók motiváltak legyenek a feladat pontos és kitartó elvégzésére (Molnár, 2003).

A PISA 2000 felmérés - a kognitív területeken kívül - a részt vevő országok 15 éves tanulóinál vizsgálta a tanulás nem kognitív tényezőit is. Felmérték, hogy a tanulók milyen tanulási stratégiákkal, motivációval rendelkeznek, milyen a tanulással kapcsolatos énképük, milyen tanulási helyzeteket preferálnak. A szakértők a tanulás kognitív, metakognitív és motivációs aspektusaira és ezek összefüggéseire voltak kíváncsiak (Artelt és mtsai, 2003). A kérdőív az önszabályozó tanulás négy területét vizsgálta: (1) tanulási stratégiák, (2) motiváció, (3) énkép és (4) tanulási helyzetek preferenciája ( $B$. Németh és Habók, 2006).

Az SZTE Oktatáselméleti Kutatáscsoportja elkészítette a PISA 2000 kérdőívének eredetivel ekvivalens magyar nyelvü verzióját. 2005 novemberében zajló nagymintás mérés keretében 193 iskola 270 tanulócsoportjának 3385 hetedik, illetve 2037 tizenegyedik évfolyamos diákja töltötte ki a kérdőívet. A vizsgálat eredményei alátámasztják korábbi kutatások tapasztalatait, illetve más megvilágításba helyezik azokat. Mind a 2000-es, mind a 2005-ös vizsgálat azt mutatja, hogy a magyar diákok a tananyag mechanikus bevésésére törekszenek, a kontroll és kidolgozó tanulási stratégiák háttérbe szorulnak a memorizáló mellett. A PISA 2000 felmérés során kiderült, hogy a vizsgált országok közül a magyar diákok tanulnak leggyakrabban memorizáló, magoló módon. A két vizsgálat között eltelt öt évben nem volt tapasztalható változás ezen a területen. Nemzetközi viszonylatban is kiugróan magas az instrumentális motivációja a magyar diákoknak, ami magyarázatul szolgálhat arra, hogy miért nem szeretnek a magyar diákok tanulni. Mindkét mérés azt mutatja, hogy a magyar tanulók nem szeretik a matematikát, az olvasás iránti érdeklődés viszont pozitívabb képet mutat. A fiatalok inkább bíznak verbális képességeikben, mint abban, hogy meg tudnak oldani egy matematika feladatot ( $B$. Németh és Habók, 2006). A kérdőív 2000 óta változáson ment keresztül. Egyes állítások maradtak, míg többeket kihagytak. Összességében jellemző azonban a kérdőívre, hogy az adott év kiemelten vizsgált területéhez kapcsolták (Artelt és mtsai, 2003; OECD, 2010, 2013). Egy példa a kidolgozó stratégiák közül: „Amikor tanulok, az új anyagot megpróbálom összefüggésbe hozni a más tantárgyakból tanultakkal.” Később: „Amikor matematikát tanulok, megpróbálom a munkát olyan dolgokkal összefüggésbe hozni, amelyeket más tárgyakból tanultam."

\section{A vizsgálat módszerei}

\section{Matematikai szöveges feladatok teszt}

A matematikai szöveges feladatok teszttel egyszerü aritmetikai müveletek, iskolai környezetböl ismert egy - és kétmüveletes szöveges feladatok, realisztikus meggondolást igénylő problémák, valamint adathiányos és fölösleges adatokat tartalmazó feladatok vizsgálatára került sor. A méröeszközt Szomju László állította össze, részben saját feladatokra építve, részben más mérőeszközből átvéve feladatot. A feladatok két, egyenként nyolc feladatot tartalmazó változatba kerültek besorolásra, A és B változat keretében. Az A változat 34 , a $B$ változat 32 itemet tartalmazott.

Mindkét változat első feladata egyszerü aritmetikai műveleteket tartalmazott. Pozitív egész számok összeadását, kivonását, szorzását és maradékos osztását kellett elvégezni a tanulóknak. Az összevonások során százas és tízes átlépésre volt szükség, helyesen kellett alkalmazni a műveleti sorrendet és a zárójelhasználatot. Ezek azok a müveletek, amelyek segítségével meg lehet válaszolni a szöveges feladatokat. A vizsgálat nem 
elsősorban a müveletvégzés begyakorlottságára irányult, hanem a matematikai modell felállítására is.

A második feladat fordított szövegezésü, egymüveletes problémára épült. Az A változat „kevesebb” utalószava az összeadás, a B változat „több” utalószava pedig a kivonás müveletének használatát kívánta meg. A már említett direkt transzlációs stratégia azonosításához kapcsolódott a példa.

A harmadik és negyedik feladat matematika-tankönyvekben, példatárakban gyakran előforduló feladattípus volt. Itt már két müveletet és magasabb szintü gondolkodási műveleteket kell végezni az eredményes megoldás érdekében. A két feladat szövege teljes egészében megegyezik a két változatban. A különbség az, hogy az A változatban az egyik, a B változatban a másik szöveghez egy - a megértést segítő - sematikus rajz található. A cél az volt, hogy az ábrákkal segítséget kapjanak a tanulók a mentális modell megalkotásához. A kiinduló hipotézis szerint a vizuális reprezentáció hozzásegíti a tanulókat a probléma megfelelő modellezéséhez, amely elvezet a helyes válaszhoz. A feladathoz Csíkos, Szitányi és Kelemen (2010) metakognícióra alapozott fejlesztő kísérlete nyújtott kiinduló pontot. A kutatásuk célja a matematikai szöveges feladatok megoldásának elősegítése volt vizuális reprezentációk tevékeny megismertetésén keresztül. A kutatók a matematikai mennyiségeket és viszonyokat modellező rajzok szerepét vizsgálták a matematikai problémamegoldást kísérö mentális folyamatokban.

Az ötödik és hatodik feladat realisztikus meggondolásokat igénylő probléma volt. Egy a szakirodalmi áttekintésben bemutatott elmélethez kapcsolódott ez a rész, melyet Csíkos Csaba 2003-as mérőeszközében alkalmazott. Ez a „buszos” és az „iskolás” (A változat), valamint a „deszkás” és a „vizes” (B változat) „párhuzamos” feladatok. A deszkás feladat adatait változtak. Az ,5 darab, egyenként 2,5 méter hosszú deszkát” helyett „,4 darab, egyenként 5 méter hosszú deszkát" szerepel a feladatban, a tört müveletek elkerülése miatt.

A hetedik feladatok adathiányosak, a kérdés megválaszolása a rendelkezésre bocsátott ismeretek alapján nem lehetséges. Az A változatban szereplő ,juhászos” feladat más országok vizsgálataiban is szerepelt, így lehetővé vált az eredmények összehasonlítása (Csikos, 2002). A B változat példája másik szituációban kérdez rá olyan adatra, amely szintén nem adható meg az ismert számadatokból. A tévedésre vezető tanulói meggyőződések (didaktikai egyezmények) létének bizonyítására szolgált a feladat.

A nyolcadik feladat szövege négy adatot tartalmazott, ezek közül kell kiválasztani a tanulóknak a kérdés megválaszolásához szükséges kettőt. Versenyeken, az újabb példatárakban egyre gyakoribbak ezek a típusú problémaszituációk. A tanulók számára feltételezetten nem annyira szokatlan ez a problémahelyzet, mint az adathiányos feladat.

\section{A tanulási szokások kérdöív szerkezete}

A kérdőív a PISA 2000 tanulói kérdőívének az eredetivel ekvivalens verziója. A magyar nyelvü változatot B. Németh Mária, Csíkos Csaba, Habók Anita és Korom Erzsébet készítette. A tanulók a kérdőívben szereplő 49 tételmondatról négyfokú Likert-skálán döntöttek arról, hogy az állítás mennyire igaz (egyáltalán nem igaz - teljes mértékben igaz), illetve milyen gyakorisággal jellemző rájuk (soha - szinte mindig). A tételmondatok az önszabályozó tanulás elméletére alapozva a tanulók tanulási szokásainak négy területét vizsgálják: (1) tanulási stratégiák, (2) motiváció, (3) énkép és (4) tanulási helyzet preferenciája. A vizsgált nem-kognitív területekre vonatkozó tételmondatok 13 változóba (skálába) szerveződnek.

A kérdőívben a tanulási stratégiák három típusa jelenik meg. A kidolgozó (elaborációs) stratégia (négy tételmondat), a memorizáló stratégia (négy tételmondat), valamint az elsajátítás szintjét ellenőrző kontroll stratégia (öt tételmondat). 
A tanulás eredményességét befolyásoló érzelmi tényezőket megfigyelő motivációt és tantárgyi motívumokat vizsgáló tételmondatok négy változóba szerveződnek. Az instrumentális motiváció (három tételmondat) olyan hajtóerőre vonatkozik, ami a későbbi karrier és jobb kereseti lehetőség, a könnyebb boldogulás lehetőségét vetíti elöre. A területhez tartozik még az olvasás iránti érdeklődés (három tételmondat), a matematika iránti érdeklődés (három tételmondat) és az igyekezet és kitartás a tanulásban (négy tételmondat).

A harmadik terület a tanulók önmagukról kialakított, motiváló hatású énképét vizsgálja. A diákok önbizalmára lehet következtetni az önhatékonyságra vonatkozó négy tételmondatra adott válasz alapján. A verbális (négy tételmondat), matematikai (három tételmondat) és általános tanulmányi énképre (három tételmondat) vonatkozó állítások információt adnak arról, hogy a tanulók mit gondolnak saját verbális és matematikai képességeikről akkor, ha egy problémával szembesülnek.

A kutatások szerint a tanulási környezet, a tanulási helyzet preferenciája is jelentős hatással van a tanulás hatékonyságára. Az iskolai környezetben történő sikeres tanuláshoz és a munka világában való boldoguláshoz is elengedhetetlen feltétel a hatékony kommunikáció és a társakkal való együttmüködés képessége. Iskolán belül és kívül egyszerre van jelen a team-munka és a versengés. A negyedik területet vizsgálja az utolsó kilenc tételmondat. Öt állítás vonatkozik a kooperatív, négy pedig a versenyorientált tanulási helyzetre (B. Németh és Habók, 2006).

\section{Minta, adatfelvétel}

A vizsgálatban két általános iskola 110 ötödik osztályos tanulója vett részt. A diákok öt osztályból kerültek ki. A tanulók eredményei valamivel az átlag felett vannak az Országos Kompetenciamérés visszajelzései alapján. A minta ugyan nem volt reprezentatív, de képet mutat a mindennapi élethelyzetekhez kötődő matematikai szöveges feladatok megoldásának eredményeiről és a résztvevők tanulási szokásairól. Az eredmények kiinduló alapul szolgálnak további tesztfejlesztéshez, valamint összefüggések feltárásához. Az adatfelvétel 2013 decemberében történt. A szöveges feladatokat matematikaórán oldották meg, a kérdöívet osztályfönöki órán töltötték ki a tanulók.

\section{Hipotézisek}

- A tanulók többsége figyelmen kívül hagyja a feladat realisztikus tartalmát.

- A tanulók körében feltárható a direkt transzlációs feladatmegoldó stratégia, azaz kizárólag számokat és kulcsszavakat keresnek a szövegben.

- Azok a tanulók, akik az adatok közötti kapcsolatot bemutató sematikus rajzot kapnak a feladat szövege mellé, jobb teljesítményt érnek el.

- Az iskolai képzés során kialakult „didaktikai egyezmény” kimutatható a válaszok alapján, a téves meggyőződések nincsenek összefüggésben a tanulmányi teljesítménynyel.

- A jobb énkép és motiváció eredményesebb matematikai teljesítménnyel jár együtt.

- A kidolgozó és kontroll tanulási stratégiák eredményesebb matematikai teljesítménynyel járnak együtt. 


\section{Az eredmények bemutatása}

\section{A matematikai szöveges feladatok teszt eredményei}

A matematikai szöveges feladatok teszt reliabilitás-mutatója az A változat esetén Cronbach $\alpha=0,885$, a $B$ változat esetén Cronbach- $\alpha=0,869$ volt. Figyelembe véve, hogy kismintás mérés történt, a teszt megbízhatósága elfogadható volt.

A felmérésben szereplő feladatok megoldottsági mutatói az 1. táblázatban szerepelnek. Az első, második és nyolcadik feladatok közvetlenül összehasonlíthatók. Az átlagok és a szórások is hasonló eredményt mutatnak a két változatban, egyedül az első feladat szórásánál tapasztalható különbség $\mathrm{p}<0,05$ szignifikancia-szinten. Összességében a feladatok tehát együtt elemezhetők a mintán.

1. táblázat. A matematika szöveges feladatok átlagai és szórásai (\% pont)

\begin{tabular}{|l|c|c|c|c|c|}
\hline \multicolumn{1}{|c|}{$A$ vált. $N=34$ item } & Átlag & Szórás & B vált. $N=32$ item & Átlag & Szórás \\
\hline$\underline{A} / \mathbf{1}$ & $\underline{\mathbf{6 7 , 4 0}}$ & $\underline{19,69}$ & $\underline{B / 1}$ & $\underline{\mathbf{6 8 , 3 8}}$ & $\underline{\mathbf{2 4 , 6 6}}$ \\
\hline$\underline{A / 2}$ & $\underline{82,35}$ & $\underline{29,70}$ & $\underline{B / 2}$ & $\underline{83,33}$ & $\underline{23,80}$ \\
\hline $\mathrm{A} / 3$ & 43,92 & 37,31 & $\mathrm{~B} / 3$ & 39,71 & 37,14 \\
\hline $\mathrm{A} / 4$ & 40,20 & 41,55 & $\mathrm{~B} / 4$ & 29,80 & 31,33 \\
\hline $\mathrm{A} / 5$ & 50,49 & 39,52 & $\mathrm{~B} / 5$ & 40,69 & 28,26 \\
\hline $\mathrm{A} / 6$ & 37,65 & 21,78 & $\mathrm{~B} / 6$ & 33,99 & 22,59 \\
\hline $\mathrm{A} / 7$ & 13,73 & 31,74 & $\mathrm{~B} / 7$ & 12,75 & 31,37 \\
\hline$\underline{A} / 8$ & $\underline{59,80}$ & $\underline{38,43}$ & $\underline{B} / 8$ & $\underline{61,27}$ & $\underline{43,39}$ \\
\hline Teljes teszt & $\mathbf{5 1 , 2 1}$ & $\mathbf{2 0 , 1 3}$ & Teljes teszt & $\mathbf{4 8 , 6 5}$ & $\mathbf{1 8 , 5 6}$ \\
\hline
\end{tabular}

Az első feladat egyszerü, a szöveges feladatok megoldásához elengedhetetlenül szükséges müveleteket tartalmazott. Ha részletesebben megvizsgáljuk a feladat nyolc itemét, akkor árnyaltabb képet kapunk. A kétjegyü számok körében végzett összeadás és kivonás, valamint a zárójel használata a tanulók túlnyomó többségének nem okozott gondot (80-92 százalék). A tanulók kb. 30 százaléka hajtotta végre helyesen a müveleti sorrendet, a maradékos osztást pedig szintén kb. 30 százaléka végezte el hibátlanul. Ezek a hiányosságok a „párhuzamos” feladatok közül a „deszkás” (A/5) és a „,buszos” (B/) példáknál okozhatnak gondot, a müveleti sorrend helytelen alkalmazása pedig a két müveletet igénylő harmadik és negyedik feladatok megoldásában képez akadályt.

A második feladat fordított szövegezésü, egymüveletes szöveges példa volt. A tanulók ezt a feladatot oldották meg a legeredményesebben. A 83 százalékpontos teljesítmény egészen magas, a kívánt müvelethez képest a fordított utalószó („kevesebb”, „több”) alig néhány megoldót tévesztett meg.

A nyolcadik feladat fölösleges adatokat is tartalmazott, a tanulónak kellett kiválogatni a válaszadáshoz szükségeseket, majd a helyes müveletet elvégezni. A 60 százalékpontos teljesítmény nem éri el a fordított szövegezésű, második feladat átlagát, de a „párhuzamos" feladatok átlagainál magasabb. Az utóbbi években egyre több hasonló szituációba kerülnek a diákok, az új taneszközök is közölnek hasonló feladatokat.

A kétműveletes és ,„párhuzamos” feladatok elemzésére külön került sor. A „párhuzamos" feladatok az 1. táblázatban sötét háttérrel szerepelnek. Ezek a példák vagy teljesen különbözőek a két változatban (,„párhuzamos” feladatok), vagy az egyik változat megoldói rajzos segítséget kaptak (harmadik és negyedik feladatok).

A tesztben két rajzzal segített feladat volt. A párjuk egy-egy rajzzal nem segített feladat volt, a különbség csak abban állt, hogy volt-e hozzájuk rajz vagy nem. A kétmintás t-pró- 
ba eredménye szerint az egyik feladat átlaga között szignifikáns a különbség $(p<0,05)$, vagyis a rajz segítette a tanulókat a feladat megoldásában, míg a másik feladat esetében a feladatok átlagai között nincs szignifikáns különbség, a sematikus rajz ennél a feladatnál nem segítette a tanulókat.

A párhuzamos feladatok, az ötödik és hatodik feladat, korábbi nemzetközi és hazai vizsgálatokban már szerepelt. Megoldásuk során a tanulóknak alkalmazni kellett a mindennapi életben szerzett tapasztalataikat. A válaszok kódolása négy kategória alapján történt.

Az ,iskola” feladat esetében két gyerek lakóhelyének távolságát kellett volna megállapítani. Külön elemzésre került, hogy azok, akik nem gondoltak arra, hogy a két gyerek lakóhelye és az iskola nem feltétlenül egy egyenesen van (a minta 82 százaléka!), összeadást vagy kivonást választottak-e inkább. 15 tanuló képzelte úgy, hogy az iskola a lakóhelyek között helyezkedik el (összeadás), 27 diák az egyik gyerek lakóhelyét az iskola és a másik gyerek lakóhelye közé gondolta elhelyezni (kivonás). Bár a feladat szövege nem utal arra, hogy a két gyerek együtt jár iskolába, a kivonás müveletét alkalmazók nagyobb száma mégis arra enged következtetni, hogy sok válaszadónál a tapasztalat befolyásolta a reprezentációt.

A „víz” feladat megoldottsága a „párhuzamos feladatok közül a leggyengébb. Itt az volt a feladat, hogy megadják, ha egy tartályba 1 liter $40^{\circ} \mathrm{C}$-os és 1 liter $80^{\circ} \mathrm{C}$-os vizet töltünk, milyen hőmérsékletü vizet kapunk. Ebben az esetben a rossz müvelet, nem realisztikus kategóriák vizsgálatára került sor. A tesztet író tanulók 84 százaléka erre a kérdésre $120^{\circ} \mathrm{C}$-ot írt válaszként. Más megadott érték volt a $3200^{\circ} \mathrm{C}$ és a $40^{\circ} \mathrm{C}$. Érdemes elgondolkozni azon, hogy a 11 éves tanulók ilyen arányban gondolják additív tulajdonságúnak a hőmérsékletet. Figyelemfelkeltő az, hogy a mai diákok sokkal kevesebb gyakorlati tapasztalattal rendelkeznek, mint gondolnánk, és ennyire irreális válaszokat is adnak.

A két adathiányos feladat közül a juhászos szintén szerepelt korábbi vizsgálatokban (Csíkos, 2002). Itt a juhász életkorát kérdeztük, azonban a tanulók csak az állatokra vonatkozóan kaptak információt. A javítás új kódolása négy kategória alapján történt. Ebben az esetben nagyobb volt a nem válaszolók aránya, valószínúleg köztük többen érezték úgy, hogy valami nem stimmel, a feladat nem válaszolható meg. Ezek a tanulók elsősorban a gyengébb teljesítményüek közül kerülnek ki. Ebben az esetben közelebb áll a jó megoldáshoz az, aki nem ad választ, mint az, aki megválaszol egy olyan kérdést, amit a megadott adatok alapján nem lehetséges. Csíkos tanulmánya említést tesz róla, hogy egy 1980-as vizsgálatban a 9-11 éves tanulók 62 százaléka válaszolta azt, hogy a feladat nem megoldható. Ennél a mintánál ez az arány jóval kevesebb, 16 százalék. A tanulók fele elosztja a birkák számát a kutyák számával, majd az eredményt a juhász koraként értelmezi. A tanulók 21 százaléka más müveletet végzett, a juhásznak irreálisan alacsony vagy magas életkort tulajdonítva. Az adatokból kiderült, hogy nem feltétlenül a gyengébb matematikai teljesítményü tanulók adták a nem realisztikus válaszokat. Ismét elgondolkodtat az, hogy vannak tanulók, akik minden áron próbálnak válaszolni és nem gondolják át, hogy a válaszuknak van-e reális alapja.

A hajós feladat hasonló arányokat mutat, mint a ,juhászos”. Ebben az esetben a hajó szélességét kellett volna megállapítani, azonban a magasságra és a hosszra vonatkozóan álltak rendelkezésre adatok. A tanulók 14 százalék vállalta fel, hogy ez nem megválaszolható kérdés. 18 százalék, bár ezt nem írja le, de legalább nem adott választ. 6 százalék próbált eredményt adni, más reális eredmény formájában, de egyértelműen utalnak rá, hogy az adatokból nem számolható ki a válasz. Ezzel a három diákkal együtt 19 azok száma, akik nem számolnak akkor, ha annak nincs semmi alapja, ugyanannyi, mint a hajós feladat esetében. 


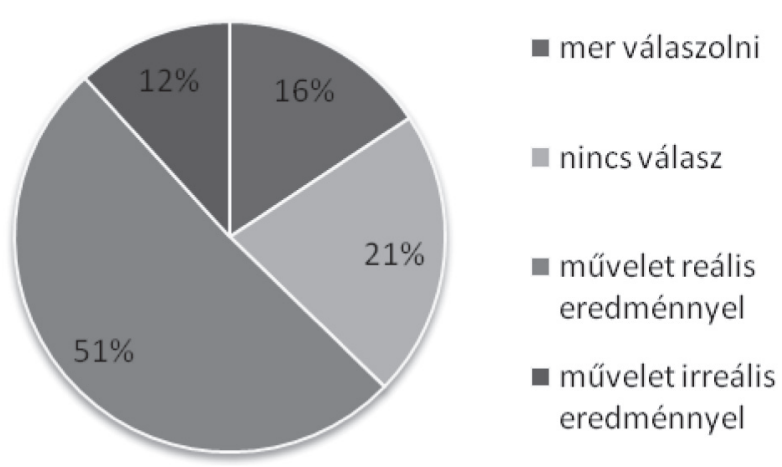

1. ábra. A ,juhászos” (A/7) feladat megoldottsága az új kódolással

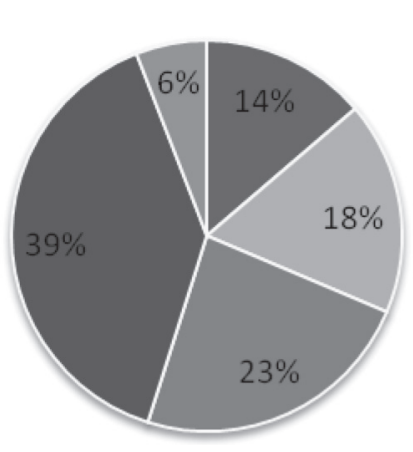

ner válaszolni

2. ábra. A „,hajós” (B/7) feladat megoldottsága az új kódolással

Az elemzésből kiderült, hogy az adathiányos feladatok külön csoportot képeznek a szöveges feladatok között. Legjobb összteljesítményt a matematika teszten azok értek el, akik mertek úgy válaszolni, hogy a megadott adatok alapján nem lehet tudni a választ. Akik nem írnak semmit, azok matematikateszt teljesítménye 40 százalékpont, meglehetősen alacsony. Gondolhatnánk, hogy ök egyébként is gyengék, a többi kérdésre sem válaszoltak. Itt azonban a nem válaszolók aránya 21 százalék, míg a többi szöveges feladat esetében ez az arány kb. 6 százalék. Valószínűleg a téves „tanulói meggyőződések”, „didaktikai egyezmények” (Csíkos, 2002) megléte, illetve hiánya figyelhető meg ebben az esetben. A jó tanulók, főleg a szorgalmasak és tekintélytisztelők jól megtanulták, hogy minden feladatnak kell lenni, lehetőleg egy megoldásának. Ennek megfelelően igyekeznek is válaszolni a kérdésre. A gyengébbek inkább felvállalják azt, hogy nem adnak választ, ha annak nincs értelme.

A három közös feladatból mindkét változat esetében egy részteszt létrehozására került sor, amelyek alapján összehasonlítható a két változatot megoldó részminta. A és B változat között a magteszt (közös feladatok) alapján a szórások $(\mathrm{F}=0,00 \mathrm{p}=0,99)$ és a kétmintás t-próba szerint az átlagok $(\mathrm{t}=-0,285 \mathrm{p}=0,78)$ között nincs szignifikáns különbség. Megállapítható, hogy a két minta ugyanazt a populációt reprezentálja. 
A magtesztek átlagai és a teljes feladatsor átlagai közötti összefüggés vizsgálatára is sor került. A magteszt pontszámának és a teljes teszt pontszámának korrelációja magas $(\mathrm{r}=0,83$ ill. 0,88$)$, vagyis a magteszt jól jellemzi az egész tesztet.

A két matematika tesztváltozat nyolc-nyolc feladata közötti összefüggéseket a 2 . és a 3. táblázatban láthatjuk.

2. táblázat. A matematika teszt A változat feladatainak korrelációi $\left({ }^{*} p<0,05 * * p<0,01\right)$

\begin{tabular}{|l|l|l|l|l|l|l|l|}
\hline & fell & \multicolumn{1}{|c|}{ fel2 } & fel3 & fel4 & fel5 & fel6 & fel7 \\
\hline fel2 & $0,300^{*}$ & & & & & & \\
\hline fel3 & $0,504^{* *}$ & $0,388^{* *}$ & & & & & \\
\hline fel4 & $0,297^{*}$ & $0,424 * *$ & $0,412^{* *}$ & & & & \\
\hline fel5 & $0,519 * *$ & n. s. & $0,521^{* *}$ & n. s. & & & \\
\hline fel6 & $0,365^{* *}$ & n. s. & $0,336^{*}$ & $0,372^{* *}$ & $0,338^{*}$ & & \\
\hline fel7 & $0,290^{*}$ & n. s. & n. s. & n. s. & n. s. & n. s. & \\
\hline fel8 & $0,389 * *$ & $0,461^{* *}$ & n. s. & n. s. & n. s. & $0,410^{* *}$ & n. s. \\
\hline
\end{tabular}

3. táblázat. A matematika teszt $B$ változat feladatainak korrelációi (* $p<0,05 * * p<0,01)$

\begin{tabular}{|l|l|l|l|l|l|l|l|}
\hline & fel1 & fel2 & fel3 & fel4 & fel5 & fel6 & fel7 \\
\hline fel2 & $0,362^{* *}$ & & & & & & \\
\hline fel3 & $0,429^{* *}$ & $0,311^{*}$ & & & & & \\
\hline fel4 & $0,506^{* *}$ & $0,357^{*}$ & n. s. & & & & \\
\hline fel5 & $0,304^{*}$ & n. s. & $0,466^{* *}$ & n. s. & & & \\
\hline fel6 & $0,367^{* *}$ & n. s. & 0,167 & $0,292^{*}$ & n. s. & & \\
\hline fel7 & n. s. & n. s. &, $308^{*}$ & n. s. & n. s. & $0,317^{*}$ & \\
\hline fel8 & $0,427^{* *}$ & n. s. & n. s. & n.s. & n. s. & $0,315^{*}$ & n. s. \\
\hline
\end{tabular}

Az első feladat a B változat 7. feladatát kivéve mindegyik feladattal szignifikáns összefüggésben van. A müveletvégzés esetén feltételezhetjük az oksági kapcsolatot, a szöveges feladatok eredményes megoldásának elengedhetetlen feltétele a megfelelő számolási készség megléte.

Mindkét változatban feltünő az ötödik és a harmadik feladatok közötti közepesnél erösebb p $<0,01$ szignifikancia-szintü korreláció. Az A változatban ez a legmagasabb érték, a $B$ változatban pedig azok közül, ahol nem szerepel az első (müveletek feladat), ez az egyedüli $\mathrm{p}<0,01$ szignifikancia-szintü érték. A két változat harmadik feladatai nem azonosak, kétmüveletes, standard (iskolai) és rajzzal segített példákról van szó. Az ötödik feladat az A változatban a „buszos”, a B változatban a „deszkás” probléma. Ha megnézzük az ötödik feladatok összefüggését a rajzzal nem segített negyedik példákkal, akkor ott már nem találunk szignifikáns korrelációkat.

Mindkét változatban a legalacsonyabb értékeket a hetedik feladat esetében találhatjuk. Az A változatban csak az első, a B változatban a harmadik és a hatodik feladatokkal van szignifikáns (gyenge közepes) összefüggése. Az A/7. (,juhászos”) feladatnak gyakorlatilag nincs összefüggése a második, negyedik, hatodik és nyolcadik feladatokkal. Valószínúleg a gyenge teljesítmény (13 százalékpontos átlag) is oka a kisebb korrelációs együtthatóknak, de minden bizonnyal más képességeket, tudást feltételez a hetedik feladat eredményes megoldása, mint a tesztben szereplö többi feladat. 


\section{A tanulási szokások kérdőiv elemzése}

A tanulási szokások és készségek kérdőív alskáláinak (változók) reliabilitás-mutatói (4. táblázat) hasonló értékeket mutatnak, mint a két korábbi vizsgálatban (PISA 2000; $B$. Németh és Habók, 2006), annak ellenére, hogy a jelen felmérésben szereplő minta szignifikánsan kisebb volt. Hasonlóan B. Németh és Habók 2006-os vizsgálatához, ebben az esetben is a tanulási stratégiák reliabilitás-mutatói a legalacsonyabbak. Az alacsonyabb értékek oka lehet az, hogy a 11 éves tanulók kevésbé tudják megítélni saját tanulási módszereiket, nem rendelkeznek megfelelő meta-tudással (B. Németh és Habók, 2006). Ha megnézzük a 13 és 17 éves korosztály értékeit, akkor ott is éppen ilyen, esetleg alacsonyabb Cronbach- $\alpha$ értékek találhatók, tehát ha ez az ok, akkor ebben nincs különbség az egyes korosztályok között. Egy másik lehetséges magyarázat, hogy a tanulók egységesebben ítélik meg saját tanulási szokásaikat. A kapott szórás értékek ezt a magyarázatot részben alátámasztják. A motivációra vonatkozó változók szórás értékeinél a tanulási szokások szórásai kisebbek. Az instrumentális motiváció reliabilitás-mutatója mindegyik vizsgálatban egészen magas $(0,87)$, föleg, ha figyelembe vesszük, hogy mindössze három itemből áll a változó. Az anyagi biztonságról és a karrier lehetőségéről már ebben a korban is kialakult képe van a tanulóknak. Összességében megállapítható, hogy a reliabilitás-mutatók kielégítőek, az elemzések elvégezhetők.

4. táblázat. A kérdöív megbizhatósága (Cronbach-alfa)

\begin{tabular}{|c|c|c|c|c|c|}
\hline \multirow[b]{2}{*}{ Skálák } & \multirow[b]{2}{*}{ Alskálák (változók) } & \multirow{2}{*}{$\begin{array}{c}\text { PISA } \\
2000 \\
15 \text { évesek }\end{array}$} & \multicolumn{2}{|c|}{$\begin{array}{c}\text { B. Németh és Habók } \\
2006\end{array}$} & \multirow{2}{*}{$\begin{array}{c}\text { 2013-as mérés } \\
11 \text { évesek }\end{array}$} \\
\hline & & & 13 évesek & 17 évesek & \\
\hline \multirow{3}{*}{$\begin{array}{l}\text { Tanulási } \\
\text { stratégiák }\end{array}$} & Kidolgozó & 0,78 & 0,64 & 0,65 & 0,70 \\
\hline & Memorizáló & 0,72 & 0,64 & 0,67 & 0,68 \\
\hline & Kontroll & 0,73 & 0,67 & 0,66 & 0,65 \\
\hline \multirow{4}{*}{ Motiváció } & Instrumentális & 0,85 & 0,84 & 0,87 & 0,87 \\
\hline & Olvasás iránti érd. & 0,85 & 0,81 & 0,84 & 0,67 \\
\hline & Matematika iránti érd. & 0,74 & 0,74 & 0,82 & 0,71 \\
\hline & Igyekezet, kitartás & 0,79 & 0,78 & 0,79 & 0,81 \\
\hline \multirow{4}{*}{ Énkép } & Önhatékonyság & 0,76 & 0,76 & 0,77 & 0,76 \\
\hline & Verbális & 0,66 & 0,79 & 0,81 & 0.74 \\
\hline & Matematikai & 0,87 & 0,81 & 0,81 & 0,78 \\
\hline & Általános tanulmányi & 0,76 & 0,80 & 0,77 & 0,84 \\
\hline \multirow{2}{*}{$\begin{array}{l}\text { Tanulási } \\
\text { helyzet }\end{array}$} & Kooperatív & 0,79 & 0,76 & 0,79 & 0,84 \\
\hline & Versenyorientált & 0,71 & 0,75 & 0,76 & 0,78 \\
\hline
\end{tabular}

Az 5. táblázatban a korábbi és jelen mérés átlagai és a jelen mérés szórásai láthatók. Legmagasabb átlaga az instrumentális motivációnak van mindegyik mérés esetén. Az adatok alátámasztják azt, hogy a 11-17 éves korosztályt a tanulásban leginkább az anyagi biztonság és a jó állás lehetősége motiválja. Három fölötti az átlaga a memorizáló tanulási stratégiának, az általános tanulmányi énképnek és a két tanulási helyzetnek (kooperatív és versenyorientált). A memorizáló, a tananyag bevésését alkalmazó tanulási stratégia a magyar diákok minden korosztályára a legjellemzőbb. Legalacsonyabb átlaga a kidolgozó stratégiának van, nem jellemző a tanulók tanulási stratégiájára ez a módszer, különösen figyelemre méltó ez a tény a nagyon gyakori memorizáló technika mellett. A másik két alacsony átlag a matematika és olvasás iránti érdeklődés. Az adatok alapján az utóbbi 15 évben ebből a szempontból nem sokat javult a helyzet. 
A tanulási helyzet preferenciája területén a kooperatív és a versenyorientált tanulás egyaránt magas értéket kapott. Pozitívan értékelhető, hogy a tanulók a négyfokú skálán magasan értékelték a kooperatív tanulást, mely a PISA 2000 vizsgálatban magyar mintán a legalacsonyabb átlagot mutatta nemzetközi összehasonlításban (Artelt és mtsai, 2003). Bár jelen vizsgálat mintája nem reprezentatív és nem azonos korosztályok szerepelnek a vizsgálatokban, azért érdemes összehasonlítani a két tanulási helyzet különbségének alakulását az évek haladtával. 2000-ben még jelentős különbség volt a 15 évesek között a versenyorientált tanulási helyzet javára, 2006-ban a 13 és 17 évesek között zárult az olló, jelen vizsgálat 11 éves tanulói esetében nincs statisztikai különbség a két tanulási helyzet preferálásában. B. Németh és Habók 2006-ban arra következtet, hogy Magyarországon is nőtt az együttmüködésen alapuló oktatási módszerek iránti érdeklődés és talán ez a kismintás mérés is ennek a folyamatnak az igazolását jelenti.

5. táblázat. A tanulási szokások kérdöív alskáláinak átlagai

\begin{tabular}{|c|c|c|c|c|c|c|}
\hline \multirow{3}{*}{ Skálák } & \multirow{3}{*}{ Alskálák (változók) } & \multirow{3}{*}{$\begin{array}{c}\text { PISA } \\
2000 \\
15 \text { évesek } \\
\text { Átlag }\end{array}$} & \multicolumn{2}{|c|}{$\begin{array}{c}\text { B. Németh és Habók } \\
2005\end{array}$} & \multirow{2}{*}{\multicolumn{2}{|c|}{$\begin{array}{c}\text { 2013-as mérés } \\
11 \text { évesek }\end{array}$}} \\
\hline & & & \multirow{2}{*}{$\frac{13 \text { évesek }}{\text { Átlag }}$} & \multirow{2}{*}{$\frac{17 \text { évesek }}{\text { Átlag }}$} & & \\
\hline & & & & & Átlag & Szórás \\
\hline \multirow{3}{*}{$\begin{array}{l}\text { Tanulási } \\
\text { stratégiák }\end{array}$} & Kidolgozó & 2,62 & 2,50 & 2,46 & 2,46 & 0,61 \\
\hline & Memorizáló & 3,14 & 3,20 & 2,94 & 3,23 & 0,61 \\
\hline & Kontroll & 2,87 & 2,90 & 2,75 & 2,98 & 0,60 \\
\hline \multirow{4}{*}{ Motiváció } & Instrumentális & 3,27 & 3,50 & 3,31 & 3,56 & 0,66 \\
\hline & Olvasás iránti érd. & 2,49 & 2,65 & 2,65 & 2,80 & 0,68 \\
\hline & Matematika iránti érd. & 2,39 & 2,47 & 2,12 & 2,76 & 0,73 \\
\hline & Igyekezet, kitartás & 2,89 & 2,82 & 2,48 & 2,97 & 0,68 \\
\hline \multirow{4}{*}{ Énkép } & Önhatékonyság & 2,58 & 2,69 & 2,52 & 2,84 & 0,63 \\
\hline & Verbális & 2,82 & 2,84 & 2,79 & 2,89 & 0,56 \\
\hline & Matematikai & 2,15 & 2,50 & 2,30 & 2,95 & 0,79 \\
\hline & Általános tanulmányi & 2,67 & 2,90 & 2,71 & 3,04 & 0,58 \\
\hline \multirow{2}{*}{$\begin{array}{l}\text { Tanulási } \\
\text { helyzet }\end{array}$} & Kooperatív & 2,11 & 2,86 & 2,69 & 3,13 & 0,69 \\
\hline & Versenyorientált & 2,66 & 3,06 & 2,82 & 3,14 & 0,63 \\
\hline
\end{tabular}

A szórások közül a két legnagyobb érték a matematikai érdeklődéshez és énképhez kapcsolódik. Ebben a két változóban polarizálódik leginkább a tanulók véleménye. Az alacsony átlagok mellett ez arra is utalhat, hogy sokan vannak, akik egyáltalán nem szívesen foglalkoznak matematikával. Ezt csak megerősíti Csapó (2002) tantárgyi attitüdökkel foglalkozó vizsgálatának eredményei. A matematikai érdeklődés esetében a tanulók több mint 20 százaléka kettőnél kisebb átlagot („,nem igaz”, „egyáltalán nem igaz”) jelölt meg, a matematikai énkép esetében ez az arány 16 százalék. Ezeknél a tanulóknál már 11 éves korban kialakul a tantárgy nagymértékü elutasítása, mely súlyos következményekhez vezet.

\section{A matematika teszt és a tanulási szokások kérdő́v összefüggései}

A következő részben a matematika magteszt és a kérdőív változóinak összefüggéseivel foglalkozunk. A Spearman-féle rangkorrelációs együtthatók minden esetben pozitívak, általában közepes vagy gyenge összefüggést jeleznek. 
6. táblázat. A matematika magteszt és a tanulási szokások kérdöiv változóinak összefüggései

$(* p<0,05 * * p<0,01)$

\begin{tabular}{|l|l|c|}
\hline \multicolumn{2}{|l|}{} & Matematika magteszt \\
\hline \multirow{4}{*}{$\begin{array}{l}\text { Tanulási } \\
\text { stratégiák }\end{array}$} & Kidolgozó & n. s. \\
\cline { 2 - 3 } & Memorizáló & n. s. \\
\cline { 2 - 3 } & Kontroll & $0,237^{*}$ \\
\hline \multirow{4}{*}{ Motiváció } & Instrumentális & $0,234^{*}$ \\
\cline { 2 - 3 } & Olvasás & $0,314^{* *}$ \\
\cline { 2 - 3 } & Matematika & $0,272^{* *}$ \\
\cline { 2 - 3 } & Igyekezet és kitartás & $0,266^{* *}$ \\
\hline \multirow{5}{*}{ Énkép } & Önhatékonyság & $0,300^{* *}$ \\
\cline { 2 - 3 } & Verbális & $0,354^{* *}$ \\
\cline { 2 - 3 } & Matematika & $0,432^{* *}$ \\
\cline { 2 - 3 } & Általános & $0,472^{* *}$ \\
\hline \multirow{2}{*}{ Tanulási helyzet } & Kooperatív & n. s. \\
\cline { 2 - 3 } & Versenyorientált & $0,221^{*}$ \\
\hline
\end{tabular}

Három olyan változója van a kérdőívnek, amelyik összefüggése a matematika teljesítménnyel nem szignifikáns. A kidolgozó tanulási stratégia ennél a korosztálynál még nem teljesen alakult ki, ez magyarázatul szolgálhat a gyenge összefüggésre. Figyelmet érdemel a memorizáló tanulási stratégia alacsony korrelációs együtthatója, különösen úgy, hogy a tanulók ezt a módszert alkalmazzák leginkább felkészülésük során. Itt valószínüsíthető az oksági összefüggés hiánya, azaz a memorizálással történő tanulás nem növeli a matematikai teljesítményt. A matematika tudáshoz kapcsolódik leginkább a megértés fogalma. Hiába tanulnak meg értelem nélkül képleteket, ha nem értik az összefüggéseket, egy idő után nem tudják felidézni ezeket. Csak az értelemgazdag, egymáshoz sok szállal kapcsolódó tudás válik hosszútávon felidézhetôvé és alkalmazhatóvá (Habók, 2004, 2007). A kontroll stratégiák gyakoribb alkalmazása, a tananyag átgondolása és ellenőrzése szignifikánsan javítja a matematikai teljesítményt.

A motivációs és az énképpel kapcsolatos változók $p<0,01$ szinten szignifikáns összefüggésben vannak a matematika teljesítménnyel. nem meglepő eredmény, hogy a matematikai és általános énkép összefüggése a legerősebb. A diákok viszonylag jól ítélik meg saját matematikai képességeiket. A motivációs értékek nem túl magasak, a diákok többsége inkább nem szeret olvasni és matematikával foglalkozni, de a korrelációs együtthatók azt mutatják, hogy fejlesztésük, elfogadottságuk növeli a matematikai teljesítményt.

Érdekes eredmény, hogy a kooperatív tanulási helyzetet előnyben részesítők nem érnek el jobb teljesítményt a matematika teszten. Azok viszont, akik versenyorientáltak, szignifikánsan jobban teljesítenek. Az ok-okozat iránya mindkét irányban értelmezhető. Feltételezhetően azok a diákok, akiknek matematikai képessége jobb, gyorsabb gondolkodásúak, kevésbé szorulnak társaik segítségére, szívesebben dolgoznak önállóan, előnyben részesítik a versenyszituációkat. Örömteli tény, hogy az együttműködő tanulási helyzeteket a tanárok és tanulók egyre inkább elfogadják és alkalmazzák, de az eredmények alapján a kooperatív tanulási helyzet nincs összefüggésben a matematikai teljesítménnyel. 


\section{Összegzés, következtetések}

A tanulmány ötödik osztályos tanulók matematikai szövegesfeladatmegoldó-képességét és tanulási szokásait, valamint a közöttük lévő kapcsolatokat vizsgálta. Az eredmények alapján az alkalmazott matematikai szöveges feladatok teszt mindkét változata megbízhatóan mért. A statisztikai próba szerint a két változatot megoldó részminta teljesítménye között nincs szignifikáns különbség, tehát ugyanazt a populációt reprezentálják. A vizsgálatban használt másik mérőeszköz a Tanulási szokások és készségek kérdőív volt, mely a PISA 2000 kérdőív magyar nyelvü verziója. A kérdőív skáláinak reliabilitás-mutatói megfelelök, ez a mérőeszköz is megbízhatóan mért.

Az első hipotézis arra vonatkozott, hogy a tanulók többsége figyelmen kívül hagyja a feladat realisztikus tartalmát. A tesztek összesen négy realisztikus meggondolást igénylö feladatot tartalmaztak. Az eredmények azt mutatták, hogy a matematikai feladatok során a diákok gyakran hagyják figyelmen kívül a valós világ körülményeit. Olyan egyszerünek tünő szituációban, mint amikor ,egy liter 40 fokos és egy liter 80 fokos vizet összeöntünk, akkor hány fokos vizet kapunk" szövegezésü feladatban, a tanulók mindössze 12 százaléka adott reális választ. Tanulságul szolgálhat ez a jelenség a természettudományos tárgyak oktatása szempontjából is.

A második hipotézis azt feltételezte, hogy a tanulók körében feltárható a direkt transzlációs feladatmegoldó stratégia, vagyis kizárólag számokat és kulcsszavakat keresnek a szövegben. Az eredmények alapján a tanulók több mint 80 százaléka jó megoldást adott. A rosszul válaszoló közel 20 százaléknál nagyrészt az említett rossz megoldási stratégia azonosítható. Érdemes ebből a szempontból megemlíteni a hetedik, adathiányos feladat eredményeit. A feladat nem volt megválaszolható a rendelkezésre álló információk alapján. Ekkor azok a tanulók is sokan közvetlen transzlációs stratégiát alkalmaztak, akik a második példát még jól megoldották. Számadatokat kerestek és A szöveg jelentésének figyelmen kivül hagyását a szakirodalmi összefoglalóban említett téves tanulói meggyózódéseknek, "didaktikai egyezményeknek" tulajdonithatjuk. A téves meggyózôdések mélyen beleivódtak a tanulók gondolkodásába, különösen iskolai kontextusban hatnak erốsen, megszokták a tanulók, hogy a feladatoknak van megoldása, és az a rendelkezésre álló feladatokból számitható ki. Változtatás csak hoszszabb fejlesztó beavatkozás útján lehetséges. Az eredmények alapján elmondható, hogy a téves tanuló meggyôzódések megléte és a matematikai teljesitmény között nincs összefüggés. müveletre utaló szavakat próbáltak azonosítani. A tanulók $\mathrm{kb}$. ötöd része egyszerü, iskolai környezetből ismert probléma esetén is direkt transzlációs stratégiát alkalmaz. Ha a probléma szokatlan a tanulók számára, akkor több mint 50 százalékuk fordul a téves stratégia alkalmazásához, mely figyelemfelkeltő eredmény.

A harmadik hipotézis abból indult ki, hogy azok a tanulók, akik az adatok közötti kapcsolatot bemutató sematikus rajzot kapnak a feladat szövege mellé, jobb teljesítményt érnek el. A feladatok tanórai környezetben és feladatgyüjteményekben gyakran előforduló problémákra épültek. Mindkét teszt változatban az egyik feladathoz rajzos segítséget kaptak a tanulók. Amelyikhez az egyik csoportnak volt rajz, a másiknak nem. Az egyik feladat esetében a rajzzal segített feladat megoldottsága szignifikánsan jobb lett, a másik 
esetében viszont alig van különbség az átlagok között. Így a két példa alapján nem lehet messzemenő következtetéseket levonni arra vonatkozóan, hogy egy ilyen „beavatkozás” segíti-e a tanulókat a feladat megfelelő értelmezésében. A hipotézisünket nem sikerült teljes mértékben igazolni. Érdemes a jelenséget azonban tovább vizsgálni, abból a szempontból, hogy melyik matematikai műveletsorhoz milyen típusú sematikus rajztípus tartozzon. A megértést segítő rajzok szerepe fontos lehet a tanítás-tanulás folyamatában és a tankönyvírók számára is.

A negyedik hipotézis azt vizsgálata, hogy az iskolai képzés során kialakult „didaktikai egyezmény" kimutatható-e a válaszok alapján, valamint a téves meggyőződések összefüggésben állnak-e a tanulmányi teljesítménnyel. A tanulók közel 70 százaléka megpróbálta kiszámítani az eredményt a tanórán megszokottakhoz hasonlóan. A nem válaszolóknak is csak a kisebb része (az egész minta 15 százaléka) meri az indoklás rovatba írni, hogy „nem megválaszolható a kérdés”. A szöveg jelentésének figyelmen kívül hagyását a szakirodalmi összefoglalóban említett téves tanulói meggyőződéseknek, „didaktikai egyezményeknek" tulajdoníthatjuk. A téves meggyőződések mélyen beleivódtak a tanulók gondolkodásába, különösen iskolai kontextusban hatnak erősen, megszokták a tanulók, hogy a feladatoknak van megoldása, és az a rendelkezésre álló feladatokból számítható ki. Változtatás csak hosszabb fejlesztő beavatkozás útján lehetséges. Az eredmények alapján elmondható, hogy a téves tanuló meggyőződések megléte és a matematikai teljesítmény között nincs összefüggés. Valószínűleg a „didaktikai egyezményeket” legalább annyira magukénak érzik a jobb tanulók is, mint a gyengébbek.

Az ötödik hipotézis azt feltételezte, hogy a jobb énkép és motiváció eredményesebb matematikai teljesítménnyel jár együtt, a hatodik hipotézis pedig kidolgozó és kontroll-stratégiák, valamint a magasabb matematikai teljesítmény közötti kapcsolatból indult ki. Ezek igazolására a Tanulási szokások és készségek kérdőívet használtuk. Nemzetközi tapasztalat, hogy a tantárgyi attitüdök és az énkép az iskolában eltöltött évek számának növekedésével egyre csökken, ezt a tényt támasztják alá a vizsgálat eredményei. A tanulók meghatározó tanulási stratégiája a memorizálás, a kérdőív változói közül a kidolgozó stratégia kapta a legalacsonyabb átlagot. A tanulási motívumok közül a legmagasabb átlagot az instrumentális motiváció adta. Nemcsak az olvasás és a matematika iránti érdeklődésnél sokkal erősebb a motívum hatása, hanem ez a változó kapta az egész kérdőív legmagasabb értékeit is. Elanyagiasodott világunkban a fogyasztói társadalom folyamatos hatásaitól a tanulók sem képesek függetleníteni magukat. A PISA mérés kimutatta, hogy a jobb állás és magasabb kereset vágya Magyarországon erősebb, mint más OECD-országokban $(B$. Németh és Habók, 2006). Tény, hogy az anyagi javak megszerzésének vágya az egyik legerősebb tanulási motívum. Örömteli jelenség, hogy a diákok egyre inkább kedvelik a kooperatív tanulási helyzeteket. Míg 15-20 évvel ezelőtt Magyarországon a tananyag frontális feldolgozása dominált, mára ebben pozitív irányú változások történtek. Egyre jellemzőbbek az osztálytermi munkára a csapatmunkán alapuló kooperatív módszerek, erről a tanúskodnak a tanulók válaszai. Fontos megjegyezni, hogy a versenyhelyzetet is kedvelik a diákok, a két tanulási helyzet egymás mellett, egymást kiegészítve müködik.

A matematikateszten nyújtott teljesítmény és a motivációs változók között szignifikáns, de gyenge közepes összefüggés tapasztalható. Szintén szignifikáns és erősebb összefüggés mutatható ki a matematikateszt eredménye és az énkép változói között. Egyrészt a diákok viszonylag jól ítélik meg saját képességeiket, másrészt az énkép javítása és a tantárgy elfogadottsága növeli az eredményességet. A kidolgozó tanulási stratégia esetében nem volt kimutatható szignifikáns összefüggés a matematikai teljesítménnyel, a kontroll stratégia esetén viszont igen. A munkáját kontrolláló, ellenőrző és visszacsatolást végző tanulók eredményesebben oldanak meg matematikai szöveges feladatokat. Jövőbeli cél a matematika teszt nagyobb mintán történő kipróbálása, valamint a változások monitorozása. 


\section{Irodalom}

Artelt, C., Baumert, J., Julius-McElvany, N. és Peschar, J. (2003): Learners for life, Student approaches to learning, Results from PISA 2000. OECD, Paris. DOI: 10.1787/9789264103917-en

B. Németh Mária és Habók Anita (2006): A 13 és 17 éves tanulók viszonya a tanuláshoz. Magyar Pedagógia, 106. 2. sz. 83-105.

Csapó Benő (2002): Iskolai osztályzatok, attitűdök, müveltség. In: uő: Az iskolai tudás. Osiris Kiadó, Budapest. 37-63.

Csíkos Csaba (2002): Hány éves a kapitány? Iskolakultúra, 12. 12. sz. 8-16.

Csíkos Csaba (2003): Matematikai feladatok megértésének problémái 10-11 éves tanulók körében. Magyar Pedagógia, 103. 1. sz. 35-55.

Csíkos Csaba (2007): Metakogníció. Müszaki Kiadó, Budapest.

Csíkos Csaba (2012): Melyik a kedvenc tantárgyad? Tantárgyi attitüdök vizsgálata a nyíltvégü írásbeli kikérdezés módszerével. Iskolakultúra, 12. 1. sz. 3-13.

Csíkos Csaba és Kelemen Rita (2009): Matematikai szöveges feladatok nehézségének és érdekességének megítélése 5. osztályos tanulók körében. Iskolakultúra, 19. 3-4. sz. 14-25.

Csíkos Csaba, Szitányi Judit és Kelemen Rita (2010): Vizuális reprezentációk szerepe a matematikai problémamegoldásban. Egy 3. osztályos tanulók körében végzett fejlesztő kísérlet eredményei. Magyar Pedagógia, 110. 2. sz. 149-166.

Csíkos, Cs., Kelemen, R. és Verschaffel, L. (2011): Fifth-grade students' approaches to and beliefs of mathematics word problem solving: a large sample Hungarian study. ZDM - International Journal on Mathematics Education, 43. 4. sz. 561-571. DOI: 10.1007/s11858-011-0308-7

D. Molnár Éva (2013): Tudatos fejlődés. Akadémiai Kiadó, Budapest.

Dignath, C., Buettner, G. és Langfeldt, H. P. (2008): How can primary school students learn self-regulated learning strategies most effectively? A meta-analysis on self-regulation training programmes. Educational Research Review, 3. sz. 101-129. DOI: 10.1016/j. edurev.2008.02.003

Dobi János (2002): Megtanult és megértett matematikai tudás. In: Csapó Benő (szerk.): Az iskolai tudás. Osiris Kiadó, Budapest. 177-199.

Habók Anita (2004): A tanulás tanulása az értelemgazdag tanulás elsajátítása érdekében. Magyar Pedagógia, 104. 4. sz. 443-470.

Habók Anita (2007): Tanulás és memorizálás. Új Pedagógiai Szemle, szeptember. 73-81.

Habók Anita (2013): Assessing some components of learning to learn. In:Gómez Chova, L., López Martínez, A. és Candel Torres, I. (szerk.): 6th International
Conference of Education, Research and Innovation. Conference Proceedings. Konferencia helye, ideje: Sevilla, Spanyolország, 2013. 11. 18-2013. 11. 20. International Association of Technology, Education and Development (IATED), Sevilla. 5890-5899.

Hoskins, B. és Fredriksson, U. (2008): Learning to Learn: What is it and can it be measured? European Commission, Joint Research Centre, Institute for the Protection and Security of the Citizen, Centre for Research on Lifelong Learning (CRELL). European Communities.

Józsa Krisztián (2006, szerk.): Az olvasási képesség fejlödése és fejlesztése. Dinasztia Tankönyvkiadó, Budapest.

Józsa Krisztián (2007): Az elsajátítási motiváció. Müszaki Kiadó, Budapest.

Józsa Krisztián és Székely Györgyi (2004): Kísérlet a kooperatív tanulás alkalmazására a matematika tanítása során. Magyar Pedagógia, 104. 3. sz. 339-362.

Kelemen Rita (2004): Egyes háttérváltozók szerepe „szokatlan” matematikai szöveges feladatok megoldásában. Iskolakultúra, 14. 11. sz. 28-38.

Mason, L. és Scrivani, L. (2004): Enhancing students' mathematical beliefs: an intervention study. Learning and Instruction, 14. sz. 153-176. DOI: 10.1016/j. learninstruc.2004.01.002

Molnár Éva (2003): Néhány személyes motívum szerepe az önszabályozó tanulásban. Magyar Pedagógia, 103. 2. sz. $155-173$.

Molnár Gyöngyvér (2001): Az életszerü feladathelyzetekben történő problémamegoldás vizsgálata. Magyar Pedagógia, 101. 3. sz. 347-372.

Nagy József (2007, szerk.): Kompetenciaalapú kritériumorientált pedagógia. Mozaik Kiadó, Szeged.

Nemzeti Alaptanterv (2012). Magyar Közlöny, 66. sz. $10639-10847$

OECD (2010): Mathematics Teaching and Learning Strategies in PISA. OECD Publishing. http://www. oecd.org/education/school/programmeforinternationals tudentassessmentpisa/46052236.pdf DOI: 10.1787/9789264039520-en

OECD (2013): PISA 2012 Results: Ready to Learn Students' Engagement, Drive and Self-Beliefs. Volume III. PISA, OECD Publishing. DOI: 10.1787/9789264201170-en

Sternberg, R. és Ben-Zeev, T. (1998): A matematikai gondolkodás folyamata. Vince Kiadó, Budapest. 41-64.

Szendrei Julianna (2005): Gondolod, hogy egyre megy? Typotex Kiadó, Budapest.

Wyndhamn, J. és Säljö, R. (1997): A szöveges feladatok és a matematikai érvelés. Iskolakultúra, 7. 12. sz. 30-46. 